\begin{tabular}{|c|}
\hline WARTA ARDHIA \\
Jurnal Perhubungan Udara \\
p-ISSN: $\underline{0215-9066}$ (print), e-ISSN: $\underline{2528-4045}$ (online), www.wartaardhia.com
\end{tabular}

\title{
Analisa Pengelolaan Produksi dan Biaya Investigasi Fasilitas Bandar Udara untuk Memprediksi Peningkatan Revenue (Studi Kasus di Bandara Depati Amir-Pangkal Pinang)
}

\section{Analyzing the Airport Production and Infrastructure facilities Invesment to Predict Increasement of Revenue (Case Study Depati Amir Aiport-Pangkal Pinang)}

\section{Maryati Karma}

Pusat Pengembangan SDM Aparatur Perhubungan, Jl. Medan Merdeka Timur no.5, Jakarta 10110 email: ir.maryatikarma@gmail.com

\section{INFO ARTIKEL}

\section{Histori Artikel:}

Diterima: 16 Juli 2018

Direvisi: 20 Desember 2018

Disetujui: 20 Desember 2018

Dipublikasi online: 17 Jan 2019

\section{Keywords:}

revenue, aviation services, nonaeronautical services, cargo services.

\section{Kata kunci:}

pendapatan, layanan penerbangan, layanan nonaeronautical, layanan kargo.

\section{Permalink/DOI:}

https://dx.doi.org/10.25104/wa.v 44i2.332.123-136

(C)2018 Puslitbang Transportasi Udara, Badanlitbang Perhubungan-Kementerian Perhubungan RI. This is an open access article under the CC BYNCSA license https:/creativecommons.org/licen ses/by-nc-sa/4.0/.

\section{ABSTRACT / ABSTRAK}

The current condition of the Depati Amir Airport managed by PT Angkasa Pura II is still declared in financial loss despite it has been invested in facilities needed for anticipating the growth of air transportation. The effort in increasing the revenue, both from aeronautical services and non aeronautical services, has also been worked out by the airport management in order to maintain positive financial performance. This research is intended to analyze the trend of airport productions, including the production of passenger, baggage, and cargo, related to the facilities development of Depati Amir Airport that aims to improve the services for customers. There are strong correlations from revenue with aeronautical services, non aeronautical services, and cargo services, as well as revenue with operating expenses and profit before tax. Whilst the correlation from revenue with investment appeared to be a weaker one. Thus, it can be concluded that the increasement of revenue is greatly influenced by the increase of flight frequency, passenger, baggage, cargo, and the efficiency of operating expense. The result of this research is expected can be used by the airport managers throughout Indonesia, whether managed by business entity such as PT Angkasa Pura or any working unit under the Ministry of Transportation, in the effort to increase the revenue as the non tax state revenues.

Pendapatan Bandara Depati Amir yang dikelola PT Angkasa Pura II masih dinyatakan merugi walaupun telah dilakukan investasi/peningkatan terhadap fasilitas yang dibutuhkan untuk mengantisipasi perkembangan sarana Transportasi Udara. Upaya meningkatkan pendapatan bandara, baik dari segi pendapatan jasa aeronautika maupun jasa non aeronautika juga telah dilakukan agar kinerja keuangan Bandara Depati Amir tidak negatif. Penelitian ini melakukan analisa trend produksi bandar udara termasuk trend produksi penumpang, bagasi dan kargo yang terkait dengan perkembangan prasarana di Bandara Depati Amir Pangkal Pinang, yang bertujuan untuk meningkatkan pelayanan kepada masyarakat (penumpang). Dalam penelitian ini juga menganalisa hubungan pendapatan dengan jasa aeronautika, jasa non aeronautia dan kargo yang diperoleh hasil mempunyai tingkat korelasi yang kuat. Selain itu juga diteliti hubungan pendapatan dengan beban usaha dan laba sebelum pajak, diperoleh hasil terdapat hubungan yang sangat kuat, sementara revenue dengan investasi ternyata tidak memiliki korelasi yang terlalu kuat. Sehingga dapat disimpulkan bahwa untuk meningkatkan pendapatan sangat dipengaruhi oleh peningkatan frekwensi penerbangan, peningkatan jumlah penumpang, bagasi dan kargo serta efisiensi beban usaha. Hasil penelitian ini diharapkan dapat digunakan oleh bandara di seluruh Indonesia, baik yang dikelola oleh PT. Angkasa Pura maupun Bandar Udara yang merupakan Unit Pelaksana Teknis Kementerian Perhubungan dalam upaya meningkatkan pendapatan bandar udara sebagai Pendapatan Negara Bukan Pajak (PNBP). 


\section{PENDAHULUAN}

Pada era globalisasi saat ini dengan pesatnya perkembangan teknologi sudah merupakan suatu tuntutan dari masyarakat untuk mendapatkan kemudahan menjangkau tujuan melalui moda transportasi udara yang cepat, aman dan nyaman.

Perkembangan pesawat dari para maskapai/airline juga meningkat terus, baik dari jumlahnya dan kapasitasnya serta karakteristik pesawatnya, hal ini sangat mempengaruhi ketersediaan pelayanan fasilitas bandar udara yaitu kebutuhan panjang landasan, luasan parkir pesawat beserta fasilitas lainnya disisi udara dan juga fasilitas terminal untuk menampung peningkatan jumlah penumpang serta lahan parkir kendaraan disisi darat.

Dengan kondisi Indonesia yang terdiri dari kepulauan maka sarana yang sangat diperlukan oleh masyarakat adalah angkutan udara yang cepat, murah dan aman serta nyaman. Untuk mendukung sarana/pesawat dapat mendarat di tempat tujuan penumpang dengan nyaman dan selamat maka perlu dipersiapkan Bandar Udara dengan fasilitas yang memenuhi Standar Nasional maupun International.

Industri penerbangan saat ini pertumbuhannya sangat pesat/luar biasa tingginya, karena konektivitas udara masih sangat dominan dan dibutuhkan oleh masyarakat, juga dengan meningkatnya pariwisata yang saat ini menjadi perhatian pemerintah agar dapat meningkatkan pendapatan negara. Angkasa Pura II dalam mengembangkan bisnisnya juga harus menjadi agen pembangunan yang dapat memberikan manfaat dan meningkatkan kesejahteraan kepada masyarakat Indonesia. Pangkal Pinang adalah suatu pulau yang memiliki tempat tempat wisata laut atau disebut wisata bahari, selain untuk leisure dipantai, melakukan diving/snorkeling dan lokasi rekreasi lainnya yang dapat menarik wisatawan.

Oleh karena itu dalam rangka mendukung peningkatan pariwisata maka perlu pengembangan fasilitas Bandar Udara Depati
Amir agar dapat melayani penumpang dengan aman, lancar dan nyaman. Faktor ekonomi akan berfokus pada pertumbuhan ekonomi daerah dan nasional, serta dampaknya pada bisnis dan penumpang. Pertumbuhan ekonomi setiap negara sangat berpengaruh terhadap industri penerbangan termasuk dinegara Asia dengan pertumbuhan GDP yang signifikan akan menciptakan keuntungan lebih baik bagi perusahaan yang terkait dengan penerbangan. PT Angkasa Pura II sebagai pengelola Bandar Udara sangatlah berkaitan langsung dengan perkembangan perusahaan penerbangan untuk menyediakan fasilitas parkir pesawat, take-off dan landing pesawat serta peralatan penunjang lainnya yang diperlukan oleh maskapai penerbangan, sedangkan yang diperlukan oleh penumpang adalah fasilitas di Terminal yang nyaman, tersedia internet, tersedia fasilitas toilet yang bersih dan nyaman, juga tersedia resto yang dapat menikmati kuliner makanan khas daerah tersebut. Hal ini merupakan peluang bisnis dari PT Angkasa Pura II sebagai Mitra yang simbiose mutualistis atau disebut kerjasama yang saling menguntungkan.

Dalam rangka meningkatkan Pelayanan Publik maka Pengelola Bandar Udara perlu menyediakan prasarana yang handal dengan bersinergi kepada para stakeholder sehingga sistem informasi dapat terintergrasi antara informasi penerbangan/angkutan udara terkait fasilitas bandar udara dapat terjalin dengan baik, yang menghasilkan tingkat pelayanan atau level of service yang diharapkan oleh masyarakat/penumpang.

Seperti diketahui bahwa sejak Bandar Udara Depati Amir - Pangkal Pinang dikelola oleh Angkasa Pura II tahun 2007 sampai dengan tahun 2017 tercatat pendapatan/ hasil produksi Aeronautika dan Non Aeronautika dari revenue Bandara Depati Amir dinyatakan masih belum menguntungkan atau masih negatif.

PT Angkasa Pura II sebagai Pengelola Bandar Udara Depati Amir adalah Badan Usaha Milik Negara yang selalu dituntut untuk mendapatkan keuntungan sebanyak 
banyaknya, namun tetap memperhatikan faktor keamanan dan keselamatan penumpang dalam pengoperasiannya sesuai dengan Standar International tanpa mengurangi pelayanan yang sangat sarat dengan aturan Nasional maupun aturan International (ICAO).

Oleh karena itu sudah merupakan tanggung jawab pengelola Bandar Udara Depati Amir untuk mencari cara/usaha bagaimana meningkatkan pendapatan tersebut. Pengelola Bandar Udara Depati Amir perlu menganalisa alat produksi yang ada saat ini untuk meningkatkan pendapatan dari bidang atau unit yang usahanya belum optimal dan masih dapat dikembangkan.

Selain menganalisa fasilitas/ alat produksi yang perlu diperhatikan adalah dukungan atau kinerja dari para staf/sumber daya manusianya, apakah kinerja bandara sudah mencapai standar/target yang diharapkan, dan juga kebijakan kebijakan tingkat pusat yang mempengaruhi kinerja Bandara bahkan membebani peningkatan pendapatan Bandar Udara Depati Amir.

\section{TINJAUAN PUSTAKA}

PT Angkasa Pura II mencanangkan bahwa ada 3 hal penting dalam Manajemen Pengelolaan Bandara yaitu Business Ecosystem, Business Strategy, dan Business Quick Win. (Mohammad Awalludin, 2017).

Business Ecosystem diuraikan sebagai 3 A yaitu Airport sebagai alat produksi utama yang menghasilkan revenue dalam bisnis kebandarudaraan terbagi dalam Aeronautika

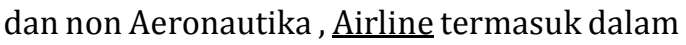
ecositem bisnis bandara yang mendatangkan penumpang sebanyak banyaknya sesuai dengan kapasitas dan kemampuan Airport , Arena adalah bandara tempat bersinergi antar stakeholder untuk mencari peluang bisnis yang harus dikomunikasikan dengan Pemerintah setempat untuk membantu mengembangkan potensi daerah yang secara langsung berdampak meningkatkan penumpang ke dan dari daerah tersebut. Angkasa Pura II sebagai badan usaha selain mencari keuntungan sebanyak banyaknya dengan biaya serendah rendahnya juga mempunyai misi sosial terhadap masyarakat sekitar Bandara.

Business Strategy yang diterapkan PT. Angkasa Pura II adalah Competitive strategy yaitu pendekatan pasar, mengingat Angkasa Pura II memiliki Captive market yang hampir tidak ada kompetitornya maka yang harus dilakukan adalah melakukan cost leadership dengan memproduksi barang barang yang biayanya lebih rendah namun kualitasnya relatif sama jika dibandingkan dengan pesaing yang ada.

Fokus bisnis yaitu memusatkan kegiatan yang mendatangkan revenue dengan tujuan khusus misalnya sebagai bandara tujuan wisatawan (tourism destination airport), arena bisnis di bandara (business area airport), pengalaman berbelanja yang terbaik di bandara (best shopping experience airport) atau Bandara sesuai dengan adat didaerah tersebut (Cultural Airport).

Strategi pendekatan pasar dengan deferensiasi dari masing masing bandara yang mempunyai ciri khas tersendiri dan unik. Pendekatan terhadap sumber daya dalam Comparative strategy harus mempunyai kemampuan bersaing yaitu airport baik secara keseluruhan antara lain kualitas Sumber Daya Manusia, sarana dan prasarana serta teknologinya yang mendukung Operasi Penerbangan berjalan secara harmonis.

Perlunya melakukan Cooperative Strategy dalam hal melakukan kerjasama dengan mitra kerja yang sudah memiliki nama (Big Name) yang reputasinya dikenal secara global yaitu provider kelas dunia, sehingga pelayanan Bandara Depati Amir dapat setara International.

Business Quick Wins yang diterapkan oleh PT Angkasa Pura II adalah melakukan perubahan dengan metode Manajemen pelayanan berbasis teknologi (IT Service Management) untuk mengidentifikasi dan mengimplementasikan peningkatan dari peluang peluang yang sejalan dengan kebutuhan bisnis. Pada umumnya bila suatu organisasi menerapkan IT Service 
Management maka akan adanya keterbatasan antara lain terbatasnya staff, terbatasnya biaya, dan komitmen yang kuat dari para pelaku bisnis untuk merubah organisasinya.

Menurut Kotter (2007), untuk Model Transformasi suatu organisasi tersebut ada 8 Langkah yaitu:

1. Adanya Kebutuhan yang urgent

2. Membentuk group yang mengarahkan

3. Membangun visi dan strategi

4. Mengkomunikasikan perubahan visi

5. Mendorong action secara menyeluruh

6. Mempercepat hasil yang nyata dalam jangka pendek Quick Wins

7. Menekankan target dan perubahan

8. Menciptakan kultur yang baru dalam suatu organisasi.

Pimpinan Perusahaan dalam menjalankan tugasnya harus dapat berperan aktif untuk meningkatkan organisasinya, baik jangka pendek maupun jangka Panjang dan membuka peluang peluang baru yang dapat meningkatkan pendapatan serta dengan cepat merubah kultur yang ada selama ini. Perlunya menganalisa strategi strategi untuk meningkatkan pendapatan / Revenue baik.

Dengan mengelola asset yang ada juga dalam menjalin hubungan dengan Pemerintah Daerah ataupun instansi instansi di Kementerian Lembaga untuk mengadakan Paket Meeting (MICE) di Pangkal Pinang Bangka.

Menurut ICAO Circular 142-AT/47 tahun 1979, Development of Non Aeronautical Revenues at Airports, bahwa Non Aeronautical dalam lingkungan bandara sangat bervariasi termasuk toko toko, restoran, bar, cafeteria, toko duty free (minuman, rokok, parfum), toko buku, toko souvenier, toko merchandise yang relative cukup mahal harganya (tas hand bag, Jam Tangan, mainan anak anak, Audio set), perkantoran Airlines, Bank bank, Money changer, Airline catering, Service Taxi, sewa kendaraan, sewa pergudangan, sewa tanah, sewa lahan atau gedung parkir kendaraan, sewa hangar pesawat, workshops, pergudangan / warehouse dll. Secara umum semua yang dijual ataupun kerja sama pada area konsesi diterminal bandara adalah sesuatu yang merupakan kebutuhan dari penumpang saat berpergian. Dan bahkan pada beberapa bandara memperhatikan kebutuhan lingkungan /komunitas sekitarnya dengan membangun super market, cinema, restaurant yang dibangun diluar daerah utama (prime space) yang dilalui penumpang dengan izin tertentu dari keamanan bandara.

\section{METODOLOGI \\ Metode Pengumpulan Data}

Teknik pengumpulan data dilakukan dengan metode metode wawancara terhadap narasumber yang kompeten dalam pengelolaan Bandara Depati Amir.

Wawancara merupakan teknik pengumpulan data yang dilakukan melalui tatap muka dan tanya jawab langsung antara pengumpul data maupun peneliti terhadap narasumber, wawancara dapat dilakukan dengan tatap muka maupun melalui telpon. (Sekaran, 2006). Dalam bentuk yang paling sederhana wawancara terdiri atas sejumlah pertanyaan yang dipersiapkan oleh peneliti dan diajukan kepada seseorang mengenai topik penelitian secara tatap muka, dan peneliti merekam jawaban jawabannya sendiri.

Dalam kebanyakan studi yang berhubungan dengan ilmu humaniora, peneliti dapat menemukan bahwa teknik wawancara pribadi merupakan instrumen yang paling baik untuk memperoleh informasi. Walaupun kita dapat memperoleh hakikat atau pendapat tertentu melalui pos atau telepon, kecuali itu ada sebagian data yang tidak mungkin diperoleh kecuali melalui wawancara tatap muka. Dalam berbagai hal peneliti menyadari pentingnya pendapat dan mendengarkan suara dan perkataan orang tentang topik penelitian. (Emzir, 2014).

Dalam Sugiyono (2014) dan Gorman \& Clayton, (1997), melakukan penelitian ini digunakan metode penelitian deskriptif kualitatif, Metode kualitatif yaitu jenis penelitian yang didesain untuk memperoleh pemahaman, penafsiran, dan subjektif. Riset Kualitatif memproses pencarian gambaran data dari konteks kejadiannya langsung, 
sebagai upaya melukiskan peristiwa sepersis kenyataannya, yang berarti membuat pelbagai kejadiannya seperti merekat, dan melibatkan perspektif (peneliti) yang partisipatif di dalam pelbagai kejadiannya, serta menggunakan penginduksian dalam menjelaskan gambaran fenomena yang diamatinya.

Ciri Kualitatif adalah Penulis kualitatif melaporkan meaning of events dari apa yang diamati penulis. (Gorman \& Clayton, 1997) Laporannya berisi amatan berbagai kejadian dan interaksi yang diamati langsung penulis dari tempat kejadian.

Penulis terlibat secara partisipatif di dalam observasinya, dia berada dan hadir di dalam kejadian tersebut. Ini yang disebut amatan langsung di sini. Maka itu, sifat kejadiannya juga bersifat spesifik. Kejadian yang memiliki nilai spesial, mempunyai kekhususan tertentu. (Santana, 2007).

\section{Analisa Korelasi Dan Regresi}

Dalam melakukan analisa hubungan korelasi antara revenue dan pendapatan jasa aero, jasa non-aero, pendapatan kargo serta analisa hubungan revenue terhadap beban usaha, laba sebelum pajak dan biaya investasi dapat digunakan analisa korelasi dan regresi dan juga melakukan Uji F dan Uji t.

\section{Uji F dan Uji t}

Uji F dikenal dengan Uji serentak atau uji Model/Uji Anova, yaitu uji untuk melihat bagaimanakah pengaruh semua variabel bebasnya secara bersama-sama terhadap variabel terikatnya. Atau untuk menguji apakah model regresi yang kita buat baik/ signifikan atau tidak baik /non signifikan. Dalam artikel ini dijelaskan tentang Uji F dan Uji t dalam penelitian. Jika model signifikan maka model bisa digunakan untuk prediksi/peramalan, sebaliknya jika non/tidak signifikan maka model regresi tidak bisa digunakan untuk peramalan.

\section{Cara Melakukan Uji F}

Uji F digunakan untuk mengetahui pengaruh variabel bebas secara bersamasama (simultan) terhadap variabel terikat.
Signifikan berarti hubungan yang terjadi dapat berlaku untuk populasi. Uji $\mathrm{F}$ dapat dilakukan dengan membandingkan $\mathrm{F}$ hitung dengan Tabel $\mathrm{F}$ dibandingkan $\mathrm{F}$ Tabel dalam Excel, jika F hitung > dari F tabel, (Ho di tolak Ha diterima) maka model signifikan atau bisa dilihat dalam kolom signifikansi pada Anova (Olahan dengan SPSS, Gunakan Uji Regresi dengan Metode Enter/Full Model). Model signifikan selama kolom signifikansi (\%) < Alpha (kesiapan berbuat salah tipe 1, yang menentukan peneliti sendiri, dalam ilmu sosial biasanya paling besar alpha $10 \%$, atau $5 \%$ atau $1 \%$ ).

Dan sebaliknya jika F hitung < F tabel, maka model tidak signifikan, hal ini juga ditandai nilai kolom signifikansi (\%) akan lebih besar dari alpha.

Penggunaan tingkat signifikansinya beragam, tergantung keinginan peneliti, yaitu 0,01 (1\%); 0,05 (5\%) dan 0,10 (10\%).

Hasil uji $\mathrm{F}$ dilihat dalam tabel ANOVA dalam kolom sig. Sebagai contoh, kita menggunakan taraf signifikansi $5 \%(0,05)$, jika nilai probabilitas $<0,05$, maka dapat dikatakan terdapat pengaruh yang signifikan secara bersama-sama antara variabel bebas terhadap variabel terikat.

Namun, jika nilai signifikansi > 0,05 maka tidak terdapat pengaruh yang signifikan secara bersama-sama antara variabel bebas terhadap variabel terikat. Uji F bisa dilakukan dengan bantuan software SPSS.

\section{Cara Melakukan Uji T}

Uji t dikenal dengan uji parsial, yaitu untuk menguji bagaimana pengaruh masing-masing variabel bebasnya secara sendiri-sendiri terhadap variabel terikatnya. Uji ini dapat dilakukan dengan mambandingkan $t$ hitung dengan $\mathrm{t}$ tabel atau dengan melihat kolom signifikansi pada masing-masing $t$ hitung, proses uji $t$ identik dengan Uji $F$ (lihat perhitungan SPSS pada Coefficient Regression Full Model /Enter). Atau bisa diganti dengan Uji metode Stepwise.

Hasil uji $t$ dapat dilihat pada tabel coefficients pada kolom sig (significance). Jika probabilitas nilai $\mathrm{t}$ atau signifikansi $<0,05$, 
maka dapat dikatakan bahwa terdapat pengaruh antara variabel bebas terhadap variabel terikat secara parsial.

Namun, jika probabilitas nilai $\mathrm{t}$ atau signifikansi > 0,05, maka dapat dikatakan bahwa tidak terdapat pengaruh yang signifikan antara masing-masing variabel bebas terhadap variabel terikat.

Sama halnya dengan Uji F, Uji t juga bisa dilakukan dengan bantuan software SPSS.

\section{Analisis Korelasi Dan Regresi}

Menurut Furqon, (2013), Statistika Terapan untuk Penelitian Korelasi dan regresi linier merupakan dua hal yang serupa tapi tak sama. Secara matematis, keduanya berhubungan sangat erat. Namun, kedua analisis tersebut didasarkan pada asumsi yang berbeda. Perbedaan utama antara keduanya terletak pada asumsi tentang peubah X. Dalam model regresi, peubah bebas (X) dan peubah terikat (Y) didefinisikan secara tegas, yaitu bahwa peubah $\mathrm{X}$ diasumsikan bersifat fiks(Fixed) dan diukur tanpa galat. Konsekwensinya, distribusi peubah Y bersifat kondisional terhadap nilai tertentu pada peubah X. Tidak seperti pada model regresi, analisis korelasi tidak didasarkan pada definisi yang tegas tentang peubah bebas $(\mathrm{X})$ dan peubah terikat $(\mathrm{Y})$; keduanya dapat bertukar tempat dan bersifat acak .Model Korelasi mengasumsikan bahwa pada suatu populasi terdapat pasangan nilai $\mathrm{X}$ dan Y; keduanya saling berhubungan dan tidak ada yang bersifat fiks.

\section{Analisis Korelasi}

Analisis korelasi adalah analisis untuk mengetahui sejauh mana hubungan (korelasi) antara dua variabel. Hubungan atau korelasi antar dua variabel tersebut dapat merupakan hubungan positif, hubungan negatif, atau tidak mempunyai hubungan. Analisis korelasi digunakan untuk mengukur kuat atau tidaknya tingkat hubungan atau korelasi antar variabel yang diteliti. Tingkat hubungan atau korelasi antar variabel tersebut dapat dilihat dari koefisien korelasinya. Koefisien korelasi yang mendekati angka +1 menunjukkan hubungan antar variabel yang kuat dan hubungan tersebut bersifat positif. Koefisien korelasi yang mendekati angka - 1 menunjukkan hubungan antar variabel yang kuat namun hubungan tersebut bersifat negatif. Sedangkan koefisien korelasi yang mendekati angka 0 (nol) menunjukkan hubungan antar variabel tersebut bersifat adalah lemah atau tidak kuat. Dengan demikian nilai koefisien korelasi adalah $-1 \leq$ $r \leq+1$.

\section{Analisis Regresi}

Analisis regresi merupakan analisis untuk mengetahui pengaruh suatu variabel terhadap variabel lain. Variabel yang mempengaruhi disebut variabel bebas (independent variable) dan variabel yang dipengaruhi disebut variabel terikat (dependent variable). Analisis regresi yang hanya terdapat satu variabel bebas dan satu variabel terikat disebut analisi regresi sederhana, sedangkan analisis regresi yang variabel bebasnya lebih dari satu disebut analisis regresi berganda.

Secara umum, analisis regresi adalah analisis mengenai ketergantungan atau pengaruh satu variabel dependen (terikat) dengan satu atau lebih variabel independent (variabel penjelas/bebas), dengan tujuan untuk mengestimasi dan/atau memprediksi rata-rata populasi atau niiai rata-rata variabel dependen berdasarkan nilai variabel independen yang diketahui. Regresi mengukur seberapa besar suatu variabel mempengaruhi variabel yang lain, sehingga dapat digunakan untuk melakukan peramalan nilai suatu variabel berdasarkan variabel lain. Hasil analisis regresi berupa koefisien regresi untuk masing-masing variable independent, yang diperoleh dengan memprediksi nilai variable dependen dengan suatu persamaan regresi. Analisa regresi ada dua: Analisa Regresi Sederhana dan Analisis Regresi Berganda.

\section{HASIL DAN PEMBAHASAN}

Kondisi Bandar Udara Depati Amir pada tahun 2007 saat diserahkan oleh Kementerian 
Perhubungan adalah: Landasan panjang $2.250 \mathrm{~m}$ x $30 \mathrm{~m}$ yang hanya mampu didarati oleh Pesawat B 737 series 200 dengan kapasitas penumpang 102 Orang dan parkir pesawat (Apron) hanya mampu menampung 3 stand pesawat. Dengan maximum pergerakan penumpang di tahun 2008 sebanyak 7.068 pesawat.

Untuk menganalisa rencana pengembangan Fasilitas Bandar Udara sesuai Standart ICAO (International Civil Aviatian Organization) maka perlu ditinjau dari kebutuhan perkembangan dari pesawat, penumpang, bagasi dan kargo sehingga dapat mengantisipasi besaran fasilitas yang dibutuhan. Dengan menggunakan regresi linier dapat diketahui trend perkembangannya serta persamaan regresinya seperti terlihat pada Gambar 2 .

\section{Analisa Trend Pertumbuhan Pesawat}

Tabel 1. Data pertumbuhan Pesawat Udara Bandara Depati Amir Tahun 2008 s.d 2017

\begin{tabular}{|c|c|c|c|c|c|}
\hline No & Tahun & $\begin{array}{c}\text { Pesawat } \\
\text { datang }\end{array}$ & $\begin{array}{c}\text { Pesawat } \\
\text { Berangkat }\end{array}$ & $\begin{array}{c}\text { Total } \\
\text { Pesawat }\end{array}$ & $\begin{array}{c}\text { Growth } \\
(\%)\end{array}$ \\
\hline 1 & 2008 & 3.534 & 3.534 & 7.068 & \\
\hline 2 & 2009 & 4.273 & 4.278 & 8.551 & $21 \%$ \\
\hline 3 & 2010 & 4.642 & 4.641 & 9.283 & $8,6 \%$ \\
\hline 4 & 2011 & 5.715 & 5.715 & 11.430 & $23,1 \%$ \\
\hline 5 & 2012 & 6.235 & 6.236 & 12.471 & $9,1 \%$ \\
\hline 6 & 2013 & 5.930 & 5.932 & 11.862 & $-4,88 \%$ \\
\hline 7 & 2014 & 5.438 & 5.438 & 10.876 & $-8,31 \%$ \\
\hline 8 & 2015 & 6.981 & 6.981 & 13.962 & $28,37 \%$ \\
\hline 9 & 2016 & 8.058 & 8.057 & 16.115 & $15,42 \%$ \\
\hline 10 & 2017 & 10.258 & 10.258 & 20.516 & $27,31 \%$ \\
\hline
\end{tabular}

Sumber: Ditjen Phb Udara, 2018

\section{TREND PESAWAT}

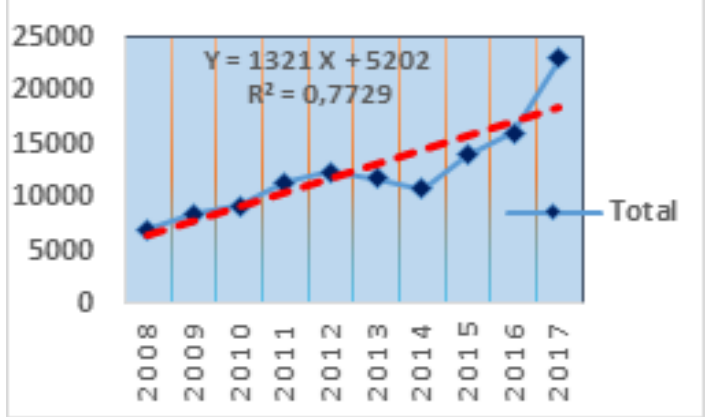

Gambar 1. Trend pertumbuhan pesawat persamaan regresi Linier sebagai berikut: $\mathrm{Y}=1321 \mathrm{X}$

$+5202$

\section{Analisa Trend Pertumbuhan Penumpang}

Tabel 2. Data Pertumbuhan Penumpang Udara Bandara Depati Amir Tahun 2008 s.d 2017

\begin{tabular}{cccccc}
\hline No & Tahun & $\begin{array}{c}\text { Penumpang } \\
\text { datang } \\
\text { (Orang) }\end{array}$ & $\begin{array}{c}\text { Penumpang } \\
\text { Berangkat } \\
\text { (Orang) }\end{array}$ & $\begin{array}{c}\text { Total } \\
\text { (Orang) }\end{array}$ & $\begin{array}{c}\text { Growth } \\
\text { (\%) }\end{array}$ \\
\hline 1 & 2008 & 393.167 & 400.508 & 793.675 & \\
\hline 2 & 2009 & 475.918 & 482.899 & 958.817 & $20,81 \%$ \\
\hline 3 & 2010 & 544.135 & 551.433 & 1.095 .568 & $14,26 \%$ \\
\hline 4 & 2011 & 657.467 & 666.793 & 1.324 .260 & $20,87 \%$ \\
\hline 5 & 2012 & 733.269 & 751.088 & 1.484 .357 & $12,09 \%$ \\
\hline 6 & 2013 & 729.732 & 737.387 & 1.467 .119 & $-1,16 \%$ \\
\hline 7 & 2014 & 698.022 & 710.404 & 1.408 .426 & $-4,00 \%$ \\
\hline 8 & 2015 & 812.017 & 823.775 & 1.635 .792 & $16,14 \%$ \\
\hline 9 & 2016 & 948.634 & 955.274 & 1.903 .908 & $16,39 \%$ \\
\hline 10 & 2017 & 1.090 .929 & 1.098 .565 & 2.048 .019 & $7,57 \%$ \\
\hline
\end{tabular}

Sumber: Ditjen Phb Udara, 2018

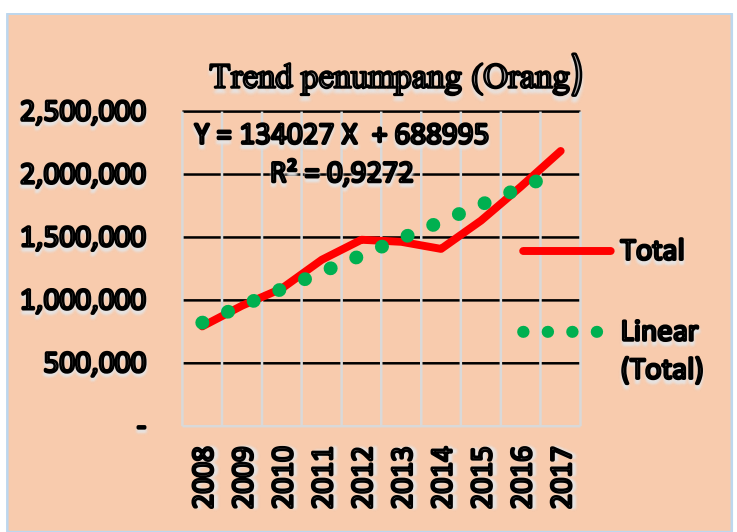

Gambar 2. Trend pertumbuhan penumpang dengan dengan persamaan regresi Linier sebagai berikut: $\mathrm{Y}=134027 \mathrm{X}+688995$

\section{Analisa Trend Pertumbuhan Bagasi}

Tabel 3. Data Pertumbuhan Bagasi Udara Bandara Depati Tahun 2008 s.d 2017 Amir

\begin{tabular}{lcccc}
\hline No & Tahun & $\begin{array}{c}\text { Bagasi } \\
\text { datang } \\
(\mathrm{Kg})\end{array}$ & $\begin{array}{c}\text { Bagasi } \\
\text { Berangkat } \\
(\mathrm{Kg})\end{array}$ & $\begin{array}{c}\text { Total } \\
\text { Bagasi } \\
(\mathrm{Kg})\end{array}$ \\
\hline $\mathbf{1}$ & 2008 & 4.363 .371 & 3.558 .596 & 7.921 .967 \\
\hline $\mathbf{2}$ & 2009 & 4.682 .633 & 4.390 .317 & 9.072 .950 \\
\hline $\mathbf{3}$ & 2010 & 5.381 .695 & 4.879 .448 & 10.261 .143 \\
\hline $\mathbf{4}$ & 2011 & 6.398 .728 & 5.578 .051 & 11.976 .779 \\
\hline $\mathbf{5}$ & 2012 & 6.071 .518 & 5.727 .850 & 11.799 .368 \\
\hline $\mathbf{6}$ & 2013 & 5.993 .630 & 5.717 .365 & 11.710 .995 \\
\hline $\mathbf{7}$ & 2014 & 5.502 .596 & 5.349 .242 & 10.851 .838 \\
\hline $\mathbf{8}$ & 2015 & 6.092 .582 & 6.166 .175 & 12.258 .757 \\
\hline $\mathbf{9}$ & 2016 & 6.641 .685 & 6.817 .189 & 13.458 .874 \\
\hline $\mathbf{1 0}$ & 2017 & 8.011 .488 & 7.680 .329 & 15.691 .817 \\
\hline
\end{tabular}

Sumber: Ditjen Phb Udara, 2018 


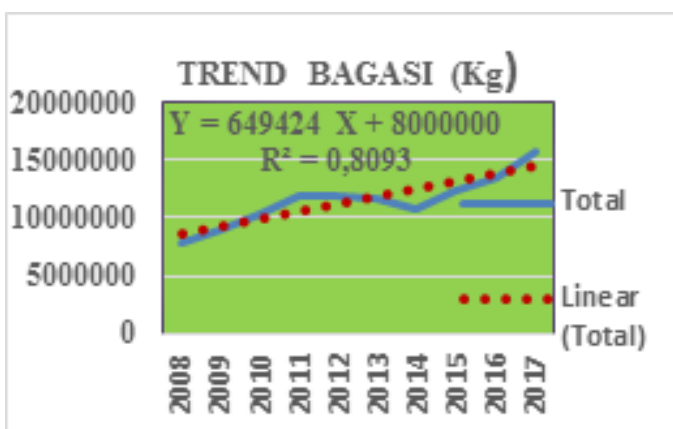

Gambar 3. Trend pertumbuhan bagasi dengan dengan persamaan regresi Linier sebagai berikut: $Y=649424 X+8000000$

\section{Analisa Trend Pertumbuhan Kargo}

Tabel 4. Data Pertumbuhan Cargo Udara Bandara Depati Amir Tahun 2008 s.d 2017

\begin{tabular}{ccccc}
\hline No & Tahun & $\begin{array}{c}\text { KARGO } \\
\text { datang } \\
(\mathrm{Kg})\end{array}$ & $\begin{array}{c}\text { KARGO } \\
\text { Berangkat } \\
(\mathrm{Kg})\end{array}$ & $\begin{array}{c}\text { Total } \\
\text { KARGO } \\
(\mathrm{Kg})\end{array}$ \\
\hline 1 & 2008 & 4.373 .518 & 951.935 & 5.325 .453 \\
\hline 2 & 2009 & 3.373 .545 & 1.085 .262 & 4.458 .807 \\
\hline 3 & 2010 & 4.816 .265 & 1.348 .229 & 6.164 .494 \\
\hline 4 & 2011 & 7.053 .888 & 2.285 .242 & 9.339 .130 \\
\hline 5 & 2012 & 6.058 .085 & 1.743 .933 & 7.802 .018 \\
\hline 6 & 2013 & 4.836 .670 & 1.237 .878 & 6.074 .548 \\
\hline 7 & 2014 & 5.141 .455 & 2.331 .762 & 7.473 .217 \\
\hline 8 & 2015 & 4.805 .803 & 1.862 .416 & 6.668 .219 \\
\hline 9 & 2016 & 5.504 .377 & 2.014 .479 & 7.518 .856 \\
\hline 10 & 2017 & 6.726 .395 & 2.420 .239 & 9.146 .634 \\
\hline
\end{tabular}

Sumber: Ditjen Phb Udara, 2018

\section{TREND CARGO (Kg)}

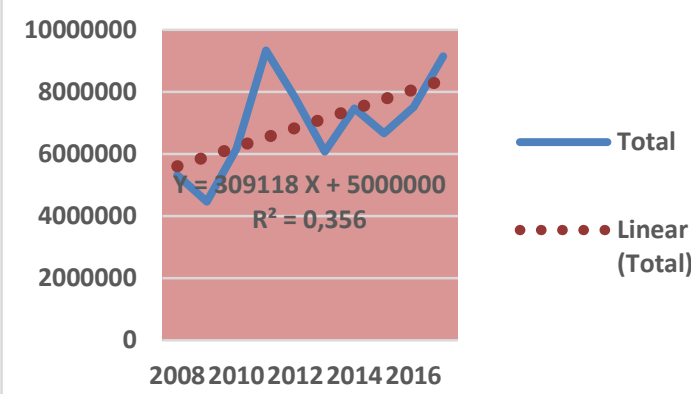

Gambar 4. Trend pertumbuhan kargo dengan dengan persamaan regresi Linier sebagai berikut: $\mathrm{Y}=309118 \mathrm{X}+$ 5000000

Pengembangan Fasilitas Bandara Depati Amir sesuai review Master Plan
Tabel 5. Data Rencana Masterplan

\begin{tabular}{|c|c|c|}
\hline Uraian Fasilitas & $\begin{array}{l}\text { Existing } \\
(2016 / 2017)\end{array}$ & $\begin{array}{l}\text { Tahap I } \\
\text { 2017-2027 }\end{array}$ \\
\hline \multicolumn{3}{|c|}{ Airside data \& Pengembangan } \\
\hline 1. Pesawat Terbesar & $\begin{array}{l}\text { B737-900ER } \\
\text { Terbatas }\end{array}$ & $\begin{array}{l}\text { B737-900ER } \\
\text { Terbatas \& } \\
\text { A321 Neo }\end{array}$ \\
\hline $\begin{array}{l}\text { 2. Movement Pesawat/ } \\
\text { Tahun }\end{array}$ & 16.235 & 21.076 \\
\hline $\begin{array}{ll}\text { 3. } & \text { Aerodrome Reference } \\
\text { Code }\end{array}$ & $4 \mathrm{C}$ & $4 \mathrm{C}$ \\
\hline $\begin{array}{ll}\text { 4. } & \text { Kategori Operasional } \\
& \text { Runway } \\
\end{array}$ & $\begin{array}{l}\text { Instrumen } \\
\text { Presisi CAT I }\end{array}$ & $\begin{array}{l}\text { Instrumen } \\
\text { Presisi CAT I }\end{array}$ \\
\hline 5. Landas Pacu (Runway) & $2250 \times 45 \mathrm{~m}$ & $2600 \times 45 \mathrm{~m}$ \\
\hline 6. $\quad$ Apron (Parkir Pesawat) & $410 \times 98 \mathrm{~m}$ & $420 \times 123 \mathrm{~m}$ \\
\hline 7. Runway Strip & $2370 \times 150 \mathrm{~m}$ & $2720 \times 300 \mathrm{~m}$ \\
\hline 8. $\quad$ RESA & $90 \times 90 \mathrm{~m}$ & $90 \times 90 \mathrm{~m}$ \\
\hline 9. $\quad$ Turning Pad & 2 buah & 2 buah \\
\hline \multicolumn{3}{|c|}{ Landside data \& Pengembangan } \\
\hline 1. Luas Lahan & $309 \mathrm{HA}$ & $309 \mathrm{HA}$ \\
\hline 2. Terminal Penumpang & 12.170 & 37.915 \\
\hline $\begin{array}{ll}\text { 3. Kapasitas penumpang } \\
\text { (orang) }\end{array}$ & 1.500 .000 & 2.900 .000 \\
\hline 4. $\quad$ Terminal Kargo & 1.626 & 2.000 \\
\hline 5. Kapasitas Kargo (Ton) & 11.182 & 26.954 \\
\hline 6. $\quad$ Area Parkir & 23.000 & 33.000 \\
\hline 7. Bangunan PKP-PK & 430 & 430 \\
\hline $\begin{array}{ll}\text { 8. } & \text { Bangunan PKP-PK } \\
\text { (SAR) }\end{array}$ & - & 156 \\
\hline 9. $\quad$ Air Traffic Control & 25 & 125 \\
\hline 10. Kantor Operasi AIRNAV & - & 300 \\
\hline 11. Main Power Station & 1.225 & 1.225 \\
\hline 12. Kantor Operasi Bandara & 445 & 445 \\
\hline $\begin{array}{ll}\text { 13. Kantor Administrasi AP } \\
\text { II }\end{array}$ & - & - \\
\hline $\begin{array}{l}\text { 14. Depot Pengisian Pesawat } \\
\text { Udara } \\
\end{array}$ & 412 & 12.000 \\
\hline 15. GSE Parking & 900 & 2.100 \\
\hline 16. GSE Maintenance & - & - \\
\hline 17. Kantor Keamanan & 177 & 177 \\
\hline 18. Masjid & 130 & 158 \\
\hline
\end{tabular}

Sumber: Bandara Depati Amir, 2018

\section{Hasil Analisa Variable Yang Mempengaruhi Pendapatan/Revenue Di Bandara Depati Amir Pangkal Pinang Bangka}

Tabel 6. Data Kinerja Bandara Depati Amir

\begin{tabular}{ccccc}
\hline Th & $\begin{array}{c}\text { Revenue } \\
\text { (Rp) }\end{array}$ & $\begin{array}{c}\text { Jasa } \\
\text { Aero } \\
\text { (Rp) }\end{array}$ & $\begin{array}{c}\text { Jasa Non } \\
\text { Aero } \\
\text { (Rp) }\end{array}$ & Kargo \\
(Rp)
\end{tabular}


Tabel 7. Correlations Revenue dengan Jasa Aero, Jasa Non Aero dan Kargo

\begin{tabular}{|c|c|c|c|c|c|}
\hline & & Revenue & $\begin{array}{l}\text { Jasa } \\
\text { Aero }\end{array}$ & $\begin{array}{l}\text { Jasa } \\
\text { Non } \\
\text { Aero } \\
\end{array}$ & Kargo \\
\hline \multirow[t]{4}{*}{$\begin{array}{l}\text { Pearson } \\
\text { Correla } \\
\text { tion } \\
\end{array}$} & Revenue & 1.000 & 0.856 & 0.920 & 0.796 \\
\hline & Jasa Aero & 0.856 & 1.000 & 0.668 & 0.419 \\
\hline & $\begin{array}{l}\text { Jasa Non } \\
\text { Aero }\end{array}$ & 0.920 & 0.668 & 1.000 & 0.746 \\
\hline & Kargo & 0.796 & 0.419 & 0.746 & 1.000 \\
\hline \multirow[t]{4}{*}{$\begin{array}{l}\text { Si.(1- } \\
\text { tailed) }\end{array}$} & Revenue & 0. & 0.007 & 0.002 & 0.016 \\
\hline & Jasa Aero & 0.007 & 0 & 0.050 & 0.175 \\
\hline & $\begin{array}{l}\text { Jasa Non } \\
\text { Aero }\end{array}$ & 0.002 & 0.050 & 0 & 0.027 \\
\hline & Kargo & 0.016 & 0.175 & 0.027 & 0 \\
\hline \multirow[t]{4}{*}{$\begin{array}{c}\mathrm{N} \\
\begin{array}{c}\text { (jumlah } \\
\text { data) }\end{array} \\
\end{array}$} & Revenue & 7 & 7 & 7 & 7 \\
\hline & Jasa Aero & 7 & 7 & 7 & 7 \\
\hline & $\begin{array}{l}\text { Jasa Non } \\
\text { Aero }\end{array}$ & 7 & 7 & 7 & 7 \\
\hline & Kargo & 7 & 7 & 7 & 7 \\
\hline
\end{tabular}

Sumber: Data diolah, 2018

Dari Tabel 7. diatas hasil analisis tersebut menunjukkan bahwa hubungan korelasi antara renenue dengan jasa aero sebesar 0,856. Hubungan Korelasi revenue dengan jasa non aero sebesar 0,920 sedangkan Hubungan korelasi Revenue dengan Kargo sebesar 0,796. Hubungan Korelasi tersebut cenderung mendekati angka 1 atau disebut hubungan kuat. Dan Hubungan Korelasi yang paling kuat adalah antara Revenue dengan jasa non aero, kemudian diikuti dengan Jasa aero dan kargo.

Dengan menggunakan tingkat kepercayaan 95\% atau alpha 0,05 sebagaimana yang digunakan dalam analisis ini, korelasi antara variabel revenue dengan jasa aero, jasa non-aero dan kargo tersebut cukup valid dan dapat diterima karena hasil analisis menunjukkan bahwa tingkat Signifikansi masing masing (Sig,1-tailed) sebagaimana tabel korelasi diatas) adalah lebih kecil dari alpha 0,05 yaitu Revenue dengan Jasa Aero 0,007, revenue dengan jasa non-aero 0,002 serta revenue dengan kargo nilainya 0,016 .

Adapun korelasi di antara variabel independen jasa aero, jasa non-aero, dan kargo sebagaimana ditunjukkan dalam Tabel
7 dapat dikatakan relatif tidak terlalu kuat atau masih di bawah 0,8 . Korelasi antara jasa aero dengan jasa non-aero sebesar 0,668 , jasa aero dengan kargo sebesar 0,419, dan jasa non-aero dengan kargo sebesar 0,746. Korelasi antar variabel independen yang relatif tidak terlalu kuat tersebut dapat dikatakan bahwa tidak terjadi kolinieritas di antara variabel independen tersebut, sehingga variabel independen jasa aero, jasa non-aero, dan Kargo dapat digunakan dalam membuat model regresi berganda sebagaimana hasil analisa dibawah ini.

Tabel 8. Coefficients

\begin{tabular}{|c|c|c|c|c|c|}
\hline Model & 1 & Constant & $\begin{array}{l}\text { Jasa } \\
\text { Aero }\end{array}$ & $\begin{array}{l}\text { Jasa } \\
\text { Non } \\
\text { Aero }\end{array}$ & Kargo \\
\hline $\begin{array}{l}\text { Unstandardized } \\
\text { coefficient }\end{array}$ & B & $\begin{array}{l}46610,3 \\
3\end{array}$ & $\begin{array}{l}0,99 \\
5\end{array}$ & $\begin{array}{l}1,01 \\
0\end{array}$ & 0,992 \\
\hline & $\begin{array}{l}\text { Std } \\
\text { Error }\end{array}$ & $\begin{array}{l}60021,0 \\
5\end{array}$ & $\begin{array}{l}0,00 \\
3\end{array}$ & $\begin{array}{l}0,00 \\
6\end{array}$ & 0,005 \\
\hline $\begin{array}{l}\text { Standardized } \\
\text { coefficient }\end{array}$ & Beta & - & $\begin{array}{l}0,48 \\
4 \\
\end{array}$ & $\begin{array}{l}0,34 \\
6 \\
\end{array}$ & 0,335 \\
\hline $\mathrm{t}$ & & 0,777 & $\begin{array}{l}298, \\
2 \\
\end{array}$ & $\begin{array}{l}156 \\
4\end{array}$ & $\begin{array}{l}184,7 \\
7\end{array}$ \\
\hline Sig, & & 0,494 & 0,00 & 0,00 & 0,00 \\
\hline $\begin{array}{l}95 \% \text { confidence } \\
\text { level for B }\end{array}$ & $\begin{array}{l}\text { Lower } \\
\text { Bound }\end{array}$ & $\begin{array}{l}- \\
144407, \\
4\end{array}$ & $\begin{array}{l}0,98 \\
4\end{array}$ & $\begin{array}{l}0,98 \\
9\end{array}$ & 0,075 \\
\hline & $\begin{array}{l}\text { Upper } \\
\text { Bound }\end{array}$ & $\begin{array}{l}237624, \\
1\end{array}$ & $\begin{array}{l}1,00 \\
6\end{array}$ & $\begin{array}{l}1,03 \\
0\end{array}$ & 1,009 \\
\hline correlations & $\begin{array}{l}\text { Zero } \\
\text { order }\end{array}$ & - & $\begin{array}{l}0,85 \\
6 \\
\end{array}$ & $\begin{array}{l}0,92 \\
0\end{array}$ & 0,796 \\
\hline & Partial & - & 1,00 & 1,00 & 1,000 \\
\hline & Part & - & $\begin{array}{l}0,35 \\
5\end{array}$ & $\begin{array}{l}0,18 \\
6 \\
\end{array}$ & 0,220 \\
\hline $\begin{array}{l}\text { Collinearity } \\
\text { statistics }\end{array}$ & $\begin{array}{l}\text { Tolera } \\
\text { nce }\end{array}$ & - & $\begin{array}{l}0,53 \\
9 \\
\end{array}$ & $\begin{array}{l}0,28 \\
9\end{array}$ & 0,431 \\
\hline & VIF & - & $\begin{array}{l}1,85 \\
5 \\
\end{array}$ & $\begin{array}{l}3,45 \\
6 \\
\end{array}$ & 2,319 \\
\hline
\end{tabular}

Sumber: Data diolah, 2018

Sehingga persamaan regresi berganda dari variable dependent revenue terhadap variable independent jasa aero, jasa non-aero, dan kargo sebagai berikut;

Revenue $=46610.333+0,995 \times 1+$

$$
1,010 \times 2+0,992 \times 3 \text {. }
$$

Keterangan;

$\mathrm{X} 1$ = Jasa aero

$\mathrm{X} 2$ = Jasa non-aero

$\mathrm{X} 3$ = Kargo

Dengan menggunakan tingkat kepercayaan $95 \%$ atau alpha 0,05 sebagaimana yang digunakan dalam analisis 
ini, koefisien regresi masing-masing variabel independen jasa aero, jasa non-aero, dan kargo tersebut cukup valid dan dapat diterima karena hasil analisis menunjukkan bahwa tingkat signifikansi masing-masing koefisien regresi sebagaimana Tabel $8 \mathrm{di}$ atas adalah lebih kecil dari alpha 0,05 (jasa aero: 0,000, jasa non-aero: 0,000, dan kargo: 0,000).

Disamping itu uji statistik dilakukan untuk melihat bagaimana pengaruh variabelvariabel independen jasa aero, jasa non-aero, dan kargo terhadap variabel dependen revenue baik secara bersama-sama atau secara sendiri-sendiri, atau untuk menguji apakah model regresi yang dibuat baik/ signifikan atau tidak baik/ tidak signifikan.

Apabila model regresi yang dibuat signifikan maka model tersebut dapat digunakan untuk memprediksi, sebaliknya apabila tidak signifikan maka model regresi tersebut tidak dapat digunakan untuk memprediksi.

Uji statistik ini digunakan uji B untuk melihat pengaruh variabel independen secara bersama-sama dan uji $t$ untuk melihat pengaruh variabel independen secara sendirisendiri.

Untuk uji $F$ dengan hipotesa yang digunakan adalah:

$\mathrm{H}_{0} \quad$ : Tidak terdapat pengaruh variabelvariable jasa aero, jasa non-aero, dan kargo secara bersama-sama terhadap variable revenue

$\mathrm{H}_{1} \quad$ : Terdapat pengaruh variabelvariabel jasa aero, jasa non-aero, dan kargo secara bersama-sama terhadap variabel revenue

$\mathrm{F}$ tabel yang digunakan dalam uji ini adalah $\mathrm{F}$ tabel dengan degree of freedom pembilang $(\mathrm{df} 1)=3$, degree of freedom penyebut $(\mathrm{df} 2)=$ 3 pada taraf signifikansi $95 \%$ (alpha 0,05 ) yaitu $\mathrm{F}$ tabel $=9,28$. Adapun kriteria uji $\mathrm{F}$ adalah : apabila nilai $\mathrm{F}$ hitung $>\mathrm{F}$ tabel maka $\mathrm{H}_{0}$ ditolak dan menerima $\mathrm{H}_{1}$ yang berarti terdapat pengaruh variabel-variabel jasa aero, jasa non aero, dan kargo secara bersamasama terhadap revenue, dan sebaliknya. Berdasarkan hasil analisis sebagaimana tabel dibawah ini.
Tabel 9. Model Summary (Dependent variable Revenue)

\begin{tabular}{|c|c|c|}
\hline Model & & 1 \\
\hline $\mathrm{R}$ & & 1,0 \\
\hline R square & & 1,0 \\
\hline $\begin{array}{r}\text { Adjusted } \\
\text { square } \\
\end{array}$ & & 1,0 \\
\hline $\begin{array}{l}\text { Std error of the } \\
\text { estimate }\end{array}$ & & 25789,47 \\
\hline \multirow[t]{5}{*}{ Change Statistics } & $\begin{array}{r}\text { R square } \\
\text { change }\end{array}$ & 1,0 \\
\hline & F change & 234784,12 \\
\hline & df 1 & 3 \\
\hline & df 2 & 3 \\
\hline & $\begin{array}{l}\text { Sig.F } \\
\text { change }\end{array}$ & 0,00 \\
\hline Durbin Watson & & 3,029 \\
\hline
\end{tabular}

Predictors: Constant, Jasa Aero, Jasa Non-Aero, Kargo

diperoleh $\mathrm{F}$ hitung $=234.784,12$, Nilai $\mathrm{F}$ hitung tersebut lebih besar dari $\mathrm{F}$ tabel, sehingga $\mathrm{H}_{0}$ ditolak dan menerima $\mathrm{H}_{1}$ yang berarti terdapat pengaruh variabel-variabel jasa aero, jasa non-aero, dan kargo secara bersama-sama terhadap variabel revenue, sehingga berdasarkan uji $\mathrm{F}$ model regresi berganda:

adalah signifikan dan dapat digunakan untuk memprediksi.

Sedangkan untuk uji $t$ dengan hipotesa yang digunakan adalah:

$\mathrm{H}_{0} \quad$ : Tidak terdapat pengaruh variable variabel jasa aero, jasa non-aero, dan kargo secara sendiri-sendiri terhadap variable revenue

$\mathrm{H}_{1} \quad$ : Terdapat pengaruh variabel-variabel jasa aero, jasa non-aero, dan kargo secara sendiri-sendiri terhadap variable revenue

Untuk uji $\mathrm{t}$ ini, $\mathrm{t}$ tabel yang digunakan adalah $\mathrm{t}$ tabel dengan degree of freedom $(\mathrm{df})=$ 6 pada taraf signifikansi $95 \%$ (alpha 0,05 ) yaitu t tabel $=1,94318$.

Adapun kriteria uji $t$ adalah: apabila nilai $t$ hitung $>\mathrm{t}$ tabel maka $\mathrm{H}_{0}$ ditolak dan menerima $\mathrm{H}_{1}$ yang berarti terdapat pengaruh variabel-variabel jasa aero, jasa non-aero, dan kargo secara sendiri-sendiri terhadap revenue, dan sebaliknya.

Berdasarkan hasil analisis diperoleh $t$ hitung untuk masing-masing variabel independen yaitu Jasa Aero $=298.2$, Jasa Non Aero $=156,4$ dan Kargo $=184,77$. Nilai t hitung 
tersebut > (lebih besar) dari t tabel, sehingga $\mathrm{H}_{0}$ ditolak dan menerima $\mathrm{H}_{1}$ yang berarti terdapat pengaruh variabel-variabel jasa aero, jasa non aero, dan kargo secara sendirisendiri terhadap variabel revenue, sehingga berdasarkan uji $\mathrm{t}$ model regresi berganda adalah signifikan dan dapat digunakan untuk memprediksi pendapatan yang diharapkan.

Selain itu dilakukan analisa hubungan korelasi antara revenue terhadap beban usaha, laba sebelum pajak dan biaya investasi yang telah dikeluarkan, dengan menggunakan metode analisa SPSS dari data Laporan Manajemen Bandara Udara Depati Amir tahun 2011 sampai dengan tahun 2017.

Tabel 10. Data Revenue beban usaha, laba sebelum pajak dan investasi.

\begin{tabular}{lccll}
\hline Th & $\begin{array}{c}\text { Revenue } \\
\text { Rp }\end{array}$ & $\begin{array}{c}\text { Beban } \\
\text { Usaha Rp }\end{array}$ & $\begin{array}{c}\text { Laba sebelum } \\
\text { Pajak Rp }\end{array}$ & $\begin{array}{c}\text { Investasi } \\
\text { Rp }\end{array}$ \\
\hline $\mathbf{2 0 1 1}$ & 30.522 .645 & 28.836 .870 & 3.417 .541 & 17.821 .668 \\
\hline $\mathbf{2 0 1 2}$ & 36.265 .458 & 30.062 .714 & 6.241 .123 & 17.824 .823 \\
\hline $\mathbf{2 0 1 3}$ & 28.278 .789 & 27.876 .026 & 402.762 & 53.470 .969 \\
\hline $\mathbf{2 0 1 4}$ & 29.299 .776 & 35.785 .711 & $(6.703 .770)$ & 13.450 .000 \\
\hline $\mathbf{2 0 1 5}$ & 34.140 .955 & 43.213 .011 & $(9.159 .461)$ & 89.859 .930 \\
\hline $\mathbf{2 0 1 6}$ & 38.737 .869 & 55.481 .491 & $(16.796 .707)$ & 38.373 .720 \\
\hline $\mathbf{2 0 1 7}$ & 53.972 .702 & 70.059 .617 & $(16.157 .201)$ & 64.111 .157 \\
\hline \multicolumn{5}{l}{ Sumber: Data diolah, 2018} \\
\end{tabular}

Dari data Tabel 10 diatas dilakukan analisa dengan SPSS dan diperoleh sebagaimana hasil berikut ini.

Tabel 11. Correlation

\begin{tabular}{|c|c|c|c|c|c|}
\hline & & Revenue & $\begin{array}{l}\text { Beban } \\
\text { Usaha }\end{array}$ & $\begin{array}{l}\text { Laba_Sb } \\
\text { lm Pajak }\end{array}$ & $\begin{array}{c}\text { Inves } \\
\text { tasi }\end{array}$ \\
\hline \multirow{3}{*}{ Revenue } & $\begin{array}{l}\text { Pearson } \\
\text { Correlation }\end{array}$ & 1 & $0.894^{* *}$ & -0.613 & 0.348 \\
\hline & $\begin{array}{l}\text { Sig. (2- } \\
\text { tailed) }\end{array}$ & & 0.007 & 0.144 & 0.445 \\
\hline & $\bar{N}$ & 7 & 7 & 7 & 7 \\
\hline \multirow{3}{*}{$\begin{array}{l}\text { Beban } \\
\text { usaha }\end{array}$} & $\begin{array}{l}\text { Pearson } \\
\text { Correlation }\end{array}$ & $0.894^{* *}$ & 1 & $-0.901^{* *}$ & 0.467 \\
\hline & $\begin{array}{l}\text { Sig. (2- } \\
\text { tailed) } \\
\end{array}$ & 0.007 & & 0.006 & 0.290 \\
\hline & $\mathrm{N}$ & 7 & 7 & 7 & 7 \\
\hline \multirow{3}{*}{$\begin{array}{l}\text { Laba_ } \\
\text { Sblm } \\
\text { Pajak }\end{array}$} & $\begin{array}{l}\text { Pearson } \\
\text { Correlation } \\
\end{array}$ & -0.613 & $-0.901^{* *}$ & 1 & -0.486 \\
\hline & $\begin{array}{l}\text { Sig. (2- } \\
\text { tailed) }\end{array}$ & 0.144 & 0.006 & & 0.269 \\
\hline & $\mathrm{N}$ & 7 & 7 & 7 & 7 \\
\hline \multirow{3}{*}{ Investasi } & $\begin{array}{l}\text { Pearson } \\
\text { Correlation }\end{array}$ & 0.348 & 0.467 & -0.486 & 1 \\
\hline & $\begin{array}{l}\text { Sig. (2- } \\
\text { tailed) }\end{array}$ & 0.445 & 0.290 & 0.269 & \\
\hline & $\mathrm{N}$ & 7 & 7 & 7 & 7 \\
\hline
\end{tabular}

**. Correlation is significant at the 0.01 level (2-tailed).

Dari hasil analisis tersebut menunjukkan bahwa hubungan korelasi antara reveue dengan beban usaha sebesar 0,894 . hubungan korelasi revenue dengan laba sebelum pajak sebesar 0,613 sedangkan hubungan korelasi revenue dengan investasi sebesar 0,348.

Dengan menggunakan tingkat kepercayaan 95\% atau alpha 0,05 sebagaimana yang digunakan dalam analisis ini, korelasi antara variabel revenue dengan beban usaha cukup valid dan dapat diterima karena hasil analisis menunjukkan bahwa tingkat signifikansi (sig,2-tailed) 0,007 adalah < (lebih kecil) dari alpha 0,05 yang berarti hubungan revenue dengan beban usaha dengan nilai 0,894 adalah signifikan pada tingkat kepercayaan 95\%.

Namun hubungan revenue dengan laba sebelum pajak menunjukkan tingkat signifikansi (sig,2 - tailed) dengan tingkat kepercayaan $95 \%$ yaitu sebesar 0,144 > (lebih besar) dari alpha 0,05 yang berarti bahwa hubungan revenue dengan laba sebelum pajak dengan nilai 0,613 adalah tidak signifikan pada tingkat kepercayaan 95\%.

Hubungan antara revenue dengan laba sebelum pajak akan signifikan pada tingkat kepercayaan $85 \%$ atau alpha 0,15 sehingga nilai signifikansi (sig,2-tailed) $0.144<$ dari alpha. jadi korelasi laba sebelum pajak dengan revenue sebesar 0,613 adalah signifikan pada tingkat kepercayaan $85 \%$, sedangkan hubungan revenue dengan investasi menunjukkan tingkat signifikansi (sig,2tailed) dengan tingkat kepercayaan 95\% yaitu sebesar 0,445 > dari alpha 0,05 berarti hubungan revenue dan investasi dengan nilai 0,348 adalah tidak signifikan pada tingkat kepercayaan $95 \%$.

\section{KESIMPULAN}

hasil penelitian didapat kesimpulan bahwa trend pertumbuhan pesawat, penumpang, bagasi dan kargo yang dianalisa dengan regresi linier menunjukan angka peningkatan secara kontinue, sejalan dengan prediksi tersebut fasilitas Bandara Depati Amir dikembangkan untuk mengantisipasi tahap I 
sampai dengan tahun 2027, dan juga telah dianalisa hubungan antara revenue/ pendapatan bandara dengan jasa aeronautika, jasa non aeronautika, dan jasa kargo serta beban usaha yang menunjukkan hubungan yang sangat kuat. sedangkan hubungan revenue dengan investasi yang dikeluarkan bandara untuk meningkatkan fasilitasnya menunjukkan tidak terlalu kuat atau tidak langsung.

Sebagaimana yang diungkapkan dalam permasalahan bahwa peningkatan investasi di Bandara Depati Amir Bangka ternyata berpengaruh tidak langsung pada perkembangan sarana transportasi udara. Sehingga untuk meningkatkan kinerja Keuangan Bandara Depati Amir harus mendorong peningkatan 4 faktor utama yaitu peningkatan jasa aeronautika, jasa non aeronautika dan Jasa kargo, serta mengefisiensikan faktor beban usaha sehingga total pendapatan/Revenue yang dihasilkan Bandara Depati Amir menjadi positif atau dapat dikatakan menghasilkan untung/laba.

\section{SARAN}

Pengelolaan operasional di bandara sangat rentan terhadap faktor safety dan peraturan peraturan internasional juga terhadap pelayanan publik, sehingga agar bandara dapat meningkatkan pendapatannya maka diharapkan Kepala Bandara dapat melakukan disruption/perubahan terhadap tata kelola pengusahaan di bandara dan meningkatkan volume penumpang dengan berbagai cara antara lain:

1. Mengadakan kerjasama dengan pihak pemerintah daerah untuk mendatangkan turis (penumpang pesawat) misalnya membuat event pertandingan bulu tangkis, lomba kuliner dsb.

2. Kerjasama dengan pariwisata dan travel untuk mengundang wisatawan bahari melakukan diving, lomba mancing mania dsb.

3. Melakukan pendekatan kepada airline untuk membuka rute rute baru misalnya: Pangkal Pinang - Medan, Pangkal Pinang -
Pontianak, Pangkal Pinang-Semarang serta menambah frekwensi pesawat.

4. Mengefisienkan biaya biaya yang menjadi beban usaha bandara, dengan melakukan koreksi secara kontinyu terhadap arus kas masuk dan keluar.

5. Mengembangkan usaha dengan memanfaatkan aset tanah yang ada disekitar bandara misalnya untuk hotel bandara lengkap dengan fasilitas untuk leisure dan MICE (Meeting, Incentive, Convention and Exhibition).

6. Mengembangkan fasilitas dan pelayanan untuk kargo sesuai kebutuhan pelanggan (Anggono Raras TS, 2010).

7. Perusahaan harus memiliki sikap entrepreneurial yang tinggi dalam menghadapi persaingan global sehingga dapat bertahan dan berkelanjutan.

\section{DAFTAR PUSTAKA}

Emzir. (2014). Metodologi Penelitian Kualitatif Analisis Data. Cet. 4. Jakarta: Rajawali Pers

Gorman, G.E., \& Clayton, P. (1997). Qualitative Research for the Information Professionals. London: Library Association Publishing.

Santana, S. (2007). Menulis Ilmiah: Metode Penelitian Kualitatif, Jakarta: Yayasan Obor Indonesia

Sugiyono. (2014). Metode Penelitian Pendidikan Pendekatan Kuantitatif, Kualitatif, dan R\&D. Bandung: Alfabeta.

Sekaran, U. (2006). Metodologi Penelitian Untuk Bisnis (Edisi 4.Bu). Jakarta: Salemba Empat.

Kotter, J. P. (2007). Leading change: Why transformation efforts fail. Harvard Business Review. https://doi.org/10.1109/EMR.2009.5235 501

International Civil Aviation Organisation (ICAO) Circular 142-AT/47 tahun 1979, Development of Non aeronautical Revenues at Airports 
Furqon, (2013), Statistika Terapan untuk penelitian. Cetakan kesembilan. Bandung: Alfabeta.

Awaluddin, M. (2017), Digital Enterprenuer Shift.
Anggono Raras TS, (2010). Potensi Bisnis Jasa Bandar Udara. Bandung: CV. Alfabeta 
